\title{
Gandhian Concept of Truth and Non-Violence
}

\author{
Nirmal Kumar Srivastava \\ Research Scholar, Department of Political Science, \\ Sri Satya Sai University of Technology and Medical Sciences ,
} Sehore,M.P.

\begin{abstract}
Mahatma Gandhi came on this earth with his message of truth and non-violence (ahimsa) at a time when the forces of aggression and violence reigned supreme on earth. Mahatma Gandhi taught us what Christ and Buddha had longed to teach long ago. He became an immortal spirit who guides us through the path of peace and non-violence. Gandhi was born in a middle class orthodox Hindu family of Gujarat, at Rajkot. Having received his early education in India, he went to London where he qualified himself as a barrister-at-law. Mahatma Gandhi was the exponent of the cult of Ahimsa or Non-violence. Like the Buddha, Christ and Chaitanya he too believed in the ultimate victory of Non-violence over violence.Force or violence, according to him, is madness which cannot sustain. 'So ultimately force or violence will bow down before non-violence'. He had waged war not only against British imperialism; rather he declared war on all the forces of unrighteousness, untruth and injustice, all the world over.The idea of truth and non-violence is at the core Mahatma Gandhi's political thought. But he himself confesses that non-violence or 'ahimsa' was not his inborn virtue. He simply states: "In the journey searching for truth I find ahimsa. I have only retrieved it, never discovered a new." Actually truth and ahimsa are closely integrated with his philosophy of life. He used to believe that ahimsa lies within the truth and similarly truth is in ahimsa. Once he thought that God is truth but later he observed that truth is God. So, he named his struggle 'Satyagraha'. The Satyagrahi will be the worshipper of non-violence which will be his life and duty.
\end{abstract}

Keywords: Truth or Satyagraha, Non-Violence or Ahimsa, Characteristics of Non-Violence, Qualities and Characteristics of Satyagrahi, Identification of Truth and God.

\section{INTRODUCTION:}

Gandhi was a great supporter of Truth and Non-violence. He had a great importance to the concept of Truth and Non-Violence,Truth or Satya, Ahimsa or Non-Violance are foundation of Gandhi's philosophy.Mohandas Gandhi was born in the western part of British-ruled India on October 2, 1869. A timid child, he was married at thirteen to a girl of the same age, Kasturbai. Following the death of his father, Gandhi's family sent him to England in 1888 to study law. There, he became interested in the philosophy of nonviolence, as expressed in the Bhagavad-Gita, Hindu sacred scripture, and in Jesus Christ's Sermon on the Mount in the Christian Bible. He returned to India in 1891, having passed the bar, but found little success in his attempts to practice law. Seeking a change of scenery, he accepted a position in South Africa for a year, where he assisted on a lawsuit.He founded the Natal Indian Congress, which worked to further Indian interests, and commanded an Indian medical corps that fought on the British side in the Boer War (1899-1901), in which the British conquered the last independent Boer republics.After the war, Gandhi's reputation as a leader grew. He became even more adamant in his personal principles, practicing sexual abstinence, renouncing modern technology, and developing satyagraha-literally, "soul- force." Satyagraha was a method of non-violent resistance, often called "non-cooperation," that he and his allies used to great effect against the white governments in South Africa.

\section{Meaning}

According to Mahatma Gandhi, ahimsa implies uttermost selflessness. It means, if anyone wants to realize himself, i.e., if he wants to search for the truth, he has to behave in such a way that others will think him entirely safe.According to Gandhi, this is the way of ahimsa. He did not consider non-killing alone to be nonviolence. To him, non-violence is not a negative concept but a positive sense of love. He talked of loving the wrong-doers, but not the wrong.He had strongly opposed any sort of submission to wrongs and injustice in an indifferent manner. He thought that the wrong-doers can be resisted only through the severance of all relations with them. 
Nature

According to Gandhi, non-violence never evades violence. On the contrary, it carries on a constant struggle against arrogance and violence. This is why he did not regard the pacifist as non-violent. He considered non-violence to be a very powerful active force. The followers of non-violence would never retreat at the sight of violence. They would rather devote themselves to the task of changing the hearts of perpetrators of violence through self-torture for establishing truth.According to Gandhi, to move fearlessly into the dreadful jaws of violence is called non-violence. Thus, in Gandhi's concept of non-violence there was no place for timidity or cowardice. He considered violence to be preferable to cowardice. While commenting on this matter in his article entitled 'The Doctrine of the Sword', he says that, given a choice between cowardice and violence, he would prefer violence. But he firmly believed that non-violence was certainly superior to violence and forgiveness was far more manly than punishment.

\section{Evaluation}

Though Mahatma Gandhi accorded the principle of 'truth and non-violence' a pivotal position in all his activities all through his life, he realised that the common people of India and even the majority of the contemporary Congress leaders had not accepted non-violence as a 'creed'. For this reason he commented that he had doubt as to how many persons fully believed in the creed of non-violence.But he thought that his movements did not at all depend on non-violent workers as believers in the creed of non-violence. He considered it to be adequate for his purpose if they followed the print principle in practice. Like those days, today also there is acute shortage of person really believing in the creed of non-violence. Consequently, clash of narrow selfish interests, struggles for power, world-wide competition for weapons of mass destruction, struggle for establishing hegemony, etc. have brought the world on the verge of a deep crisis.In the opinion of the followers of Gandhi, the relevance of the Gandhian concept of truth and non-violence cannot be ignored or denied at all. However, the Marxists think it to be a utopian idea as it is impossible to put the principle in practice.

\section{Satyagraha, the Centre of Gandhi's Contribution to the Philosophy of Nonviolence}

It will be good here to examine what Stanley E. Jones calls "the centre of Gandhi's contribution to the world". All else is marginal compared to it. Satyagraha is the quintessence of Gandhism. Through it, Gandhi introduced a new spirit to the world. It is the greatest of all Gandhi's contribution to the world.

\section{What is Satyagraha?}

Satyagraha (pronounced sat-yah-graha) is a compound of two Sanskrit nouns satya, meaning truth (from 'sat'- 'being' with a suffix 'ya'), and agraha, meaning, "firm grasping" (a noun made from the agra, which has its root 'grah'- 'seize', 'grasp', with the verbal prefix 'a' - 'to' 'towards). Thus Satyagraha literally means devotion to truth, remaining firm on the truth and resisting untruth actively but nonviolently. Since the only way for Gandhi getting to the truth is by nonviolence (love), it follows that Satyagraha implies an unwavering search for the truth using nonviolence. Satyagraha according to Michael Nagler literally means 'clinging to truth,' and that was exactly how Gandhi understood it: "clinging to the truth that we are all one under the skin, that there is no such thing as a 'win/lose' confrontation because all our important interests are really the same, that consciously or not every single person wants unity and peace with every other" Put succinctly, Satyagraha means 'truth force', 'soul force' or as Martin Luther Jr would call it 'love in action.' Satyagraha has often been defined as the philosophy of nonviolent resistance most famously employed by Mahatma Gandhi, in forcing an end to the British domination. Gene Sharp did not hesitate to define Satyagraha simply as "Gandhian Nonviolence."

\section{Gandhi View of Satyagraha}

Satyagraha was not a preconceived plan for Gandhi. Event in his life culminating in his "Bramacharya vow", prepared him for it. He therefore underlined:Events were so shaping themselves in Johannesburg as to make this self-purification on my part a preliminary as it were to Satyagraha. I can now see that all the principal events of my life, culminating in the vow of Bramacharya were secretly preparing me for it.

\section{The Basic Precepts of Satyagraha}

There are three basic precepts essential to Satyagraha: Truth, Nonviolence and self-suffering. These are called the pillars of Satyagraha. Failure to grasp them is a handicap to the understanding of Gandhi's non violence. These three fundamentals correspond to Sanskrit terms:

- Sat/Satya - Truth implying openness, honesty and fairness

- Ahimsa/Nonviolence - refusal to inflict injury upon others.

- Tapasya - willingness to self-sacrifice. 


\section{Qualities of a Satyagrahi(Nonviolence Activist)}

Gandhi was quite aware that there was need to train people who could carry on with his Satyagraha campaigns. He trained them in his "Satyagraha Ashrams". Here are some of the basic qualities of expected of a Satyagrahi.

- A Satyagraha should have a living faith in God for he is his only Rock.

- One must believe in truth and nonviolence as one's creed and therefore have faith in the inherent goodness of human nature.

- One must live a chaste life and be ready and willing for the sake of one's cause to give up his life and his possessions.

- One must be free from the use any intoxicant, in order that his reason may be undivided and his mind constant.

- One must carry out with a willing heart all the rules of discipline as may be laid down from time to time.

- One should carry out the jail rules unless they are especially dense to hurt his self-respect.

- A satyagrahi must accept to suffer in order to correct a situation.

\section{CONCLUSION:}

Gandhiji was an angelic being, a source of inspiration to his people. He was a messiah for the tortured and oppressed humanity. He is a spirit of non-violence, peace and love. We can say that both Truth and NonViolence are closely interrelated. They are the same sides of a same coin. A critical account of the Gandhianconept of Non-Violence shows that Gandhi was not aware of the deep rooted aggressive instinct in man. Contemporary psychologist have pointed out that this instinct plays a major role in the human mental life. Gandhi did not play sufficient attention to it. His account of Non-Violence seems to be more dependent on his readings of religious texts than on psycho-social considerations. This is a major critical point that may be raised against the Gandhian conception of NonViolence. If Non-Violence is the expression of the life-instinct within man then violence is the expression of the death-instinct.

\section{REFERENCE:}

[1] M. SHEPARD, Mahatma Gandhi and his Myths, Civil Disobedience, Nonviolence and Satyagraha in the Real World, Los Angeles,

[2] Shepard Publications, 2002, http://www.markshep.com/nonviolence/books/myths.html

[3] M. K. GANDHI, All Men Are Brothers, Autobiographical Reflections, Krishna Kripalani (ed.), New York; The Continuum Publishing Company, 1990, vii.

[4] M. K. GANDHI, Young India, 22-11-1928, The Collected Works of Mahatma Gandhi, Vol. xxxviii, Ahmedabad; Navajivan Trust, 1970, 69.

[5] M. K. GANDHI, Young India, 20-12-1928, in ibidem, 247.. The New Zion's Herald, July/August 2001, vol. 175 , issue $4,17$.

[6] M. K. GANDHI, An Autobiography or The Story of My Experiments With truth, Ahmedabad; Navajivan Trust, 2003, 254.

[7] NIRMAL KUMAR BOSE, Selections from Gandhi, Ahmedabad; Navajivan Trust, 1948,154. 